\title{
Hesio Cordeiro: lembranças do seu legado humanista e civilizatório
}

| ${ }^{1}$ Nelson Rodrigues dos Santos |

1 Universidade Estadual de Campinas, Campinas - SP, Brasil (nelsonrs@fcm.unicamp.br). ORCID: 0000-0001-8607-3339

Recebido em: 20/06/2021

Aprovado em: 03/08/2021

Revisado em: 23/08/2021

DOI: http://dx.doi.org/10.1590/S0103-73312021310305

Conheci Hesio no início dos anos 1970, quando, em encontro por ele proposto no Rio de Janeiro por ocasião de minha participaçáo em reunião da Associação Brasileira de Educaçáo Médica, poderíamos conversar sobre um texto meu sobre Atenção Primária à Saúde realizada por convenio entre a Universidade Estadual de Londrina e a Prefeitura Municipal. Marcou-me, entre outros aspectos, o interesse dele pela atenção integral, pela universalidade incluindo os contribuintes da Previdência Social, pela resolutividade e pelo custo. Do meu lado, fui despertado pelo objeto maior de interesse e dedicação dele: a aproximação da crise nacional na assistência médica previdenciária nos serviços próprios e contratados no mercado lucrativo, crise essa no campo de $90 \%$ dos recursos públicos à saúde sob gestáo do Estado brasileiro.

Esse encontro inicial desdobrou-se em permanente intercâmbio de análises, proposiçóes e militância pelo que viria a ser um sistema público universal de qualidade. Para Hesio, o conhecimento, avaliação e proposiçóes conjuntas in loco de iniciativas inovadoras de caráter público, com potencial de evoluírem, se consolidarem e se reproduzirem o mais rapidamente, era sempre prioritário e inadiável; assim foi com as iniciativas dos anos 1970 no bairro de Sáo José do Murialdo, em Porto Alegre, Montes Claros e regiāo em Minas Gerais, os Centros de Saúde-Escola no 
Estado de São Paulo e inúmeras outras. Seu eixo básico de pesquisa e produção de conhecimento no Instituto de Medicina Social da UERJ era a crise na saúde previdenciária, objeto do seu doutorado sobre o complexo médico-empresarial, e sem perder a visão de futuro na perspectiva de expansão de rede básica de saúde de qualidade, rumo a um sistema universal de saúde.

Quanto à crise previdenciária, era consequente aos macrodesvios pela ditadura, de recursos previdenciários para as grandes obras federais, e também ao incontrolável superfaturamento nos contratos previdenciários com a rede hospitalar privada contratada, que ao final da década andava perto de $35 \%$ do orçamento previdenciário, pondo em xeque os demais benefícios. Só ilustrando, em 1976 foi aprovado macroempréstimo a fundo perdido pela Caixa Econômica Federal, com recursos do Fundo de Assistência Social, para expansão da rede hospitalar privada nas regióes Norte, Nordeste e Centro-Oeste, mas em três anos 85\% estavam construídos no Sudeste e Sul, constando no ato da inauguração, o anúncio do contrato de prestação de serviços para o Instituto Nacional de Assistência Médica da Previdência Social (INAMPS). Em 1979, o Ministério da Previdência e Assistência Social, por meio de comissão especial, introduziu no INAMPS forte racionalização na compra de serviços no setor privado, visando conter os superfaturamentos, com vistas a manter um teto de $25 \%$ dos recursos previdenciários.

Em meados dos anos 1970, participei em duas reuniôes no IMS a convite de Hesio, quando conheci Reinaldo Guimarães e José Luís Fiori, que, com Hesio, elaboravam e debatiam o que veio a ser o histórico texto "A questão democrática na área da Saúde" (CEBES, 1980). Esse texto foi o ponto de partida assumido pelos demais núcleos nacionais de estudiosos, formuladores e militantes por um sistema de saúde socialmente justo e viável. Foi o texto básico do histórico 1o Simpósio de Política Nacional de Saúde na Câmara dos Deputados Federais em 1979, que o debateu e aprovou no seu relatório final. Destaco a coincidência da criação, também em meados dos anos 1970, do Centro Brasileiro de Estudos em Saúde (CEBES), que nucleou em nível nacional a formulação e divulgação de textos, experiências e proposiçôes voltados para a criação e ampliação do movimento pela reforma sanitária brasileira, onde Hésio também sempre militou em elevado nível.

Sob o ângulo do processo do binômio formulação-mobilização, Hesio tornou-se, desde os anos 1970, uma das maiores referências nacionais no seio do movimento da reforma sanitária, da formulação e construção de novo modelo da atenção à 
saúde (CORDEIRO, 1980), e na ditadura, somando a militância pelas liberdades democráticas. Destaco outro legado seu, não menos notável, que foi seu ângulo pessoal sempre afável, solícito, paciente, com incrível sensibilidade de escuta e abertura para o contraditório. Legou também inusitada persistência, sempre surpreendente nos debates, como também disponibilidade para aprender com o interlocutor e também com o contendor. Lembro-me de tensa contenda em evento no campo da reforma sanitária, ameaçando inabdicável unidade perante a hegemonia do mercado na política do Estado: durante várias horas, nosso lado revezava para um lanche, um descanso ou ida ao banheiro, e Hesio desdobrou-se sem arrefecer, mantendose controlado do começo ao fim, suando e conseguindo importante acordo em função do que era maior. De maneira entranhada à sua atuação intelectual e política coerente diuturna, Hesio era uma pessoa intrinsicamente doce.

Em 1983, na presidência do INAMPS, Hesio construiu competência de gestão e suporte político para iniciativas até então impossíveis, como o convenio Açôes Integradas de Saúde (AIS) com municípios com rede de Atenção Básica Universal à Saúde, que elevou entre 20 e $50 \%$ os gastos municipais com a expansão e qualificação dessa rede. Os valores dos procedimentos de saúde repassados pelo INAMPS possibilitavam a desejada ampliaçáo e qualificação, e eram, em média, metade dos valores de compra dos mesmos procedimentos realizados pelos serviços privados contratados. Em 1986, evoluiu para o convenio Sistema Unificado Descentralizado de Saúde (SUDS) com os estados, para ampliação e qualificação da prestação pública de serviços universais e integrais de saúde. Hesio e seu primeiro escaláo dirigente do INAMPS ousaram viabilizar alternativas públicas de alto nível, adentrando espaços de megainteresses do mercado na saúde. Essa era a conjuntura em que foi realizada a histórica $8^{\text {a }}$ Conferência Nacional de Saúde, por Hesio coordenada.

Nos mais de trinta anos da vigência legal do SUS, Hesio manteve-se sempre como referência e esteio ativo pela continuidade de todos os esforços que vêm se acumulando pela implementação, na prática, dos seus princípios e diretrizes. Exemplificamos pelos que mal saíram do papel, como o financiamento, a atenção básica universal de alta resolutividade, a regionalização da oferta da atenção integral à saúde, a equidade, a política de recursos humanos para a saúde, o caráter efetivamente complementar dos serviços privados contratados e o financiamento público dos planos privados de saúde com vultosa renúncia fiscal a esse mercado, que dispóe a esse segmento, que atende $25 \%$ da população, mais de $50 \%$ do gasto 
total com saúde no país - todos até hoje dependentes da efetiva democratização do Estado, pano de fundo dos debates constitucionais.

Em uma feita Hesio, sabendo que eu estava em reuniáo de trabalho no Rio, convenceu-me a adiar meu retorno por um dia, a fim de participar com ele, em Itabuna, na Bahia, de importante evento de saúde promovido pela Prefeitura Municipal, cujo Prefeito era Ubaldo Dantas, que em 1979, como deputado federal, coordenou e relatou o histórico $1^{\text {o }}$ Simpósio de Política Nacional de Saúde. Em outra feita, Hesio e eu fomos solicitados por um companheiro da velha guarda da Reforma Sanitária que queria nos ouvir para decidir sobre convite para alto cargo público, em momento político bastante delicado. Foram horas de trocas de ideias, em alguns momentos com mais veemência da minha parte, com base em fatos inusitados, comprovados e constrangedores. Sem subestimar e afastar esses fatos, Hesio ponderou conjunturas anteriores, conjuntura do momento, fatores geradores dos fatos e perspectivas, em torno do que amadurecemos conclusão conjunta.

Para mim, esse era o Hesio.

\section{Referências}

CEBES - CENTRO BRASILEIRO DE ESTUDOS DE SAÚDE. A questão democrática na área da Saúde. Saúde em Debate. 9:11-13, 1980.

CORDEIRO, H. A indústria da saúde no Brasil. Rio de Janeiro: Ediçôes Graal, 1980. 